\title{
Update on the biology and management of renal cell carcinoma
}

\author{
Janice P Dutcher
}

Correspondence to

Dr Janice P Dutcher, Cancer Research Foundation, Chappaqua, NY 10514, USA; jpd4401@aol.com

Accepted 30 October 2018 Published Online First 18 November 2018

\section{Check for updates}

(C) American Federation for Medical Research 2019. No commercial re-use. See rights and permissions. Published by BMJ.

To cite: Dutcher JP.

$J$ Investig Med

2019;67:1-10.

\begin{abstract}
Renal cell cancer (RCC) (epithelial carcinoma of the kidney) represents $2 \%-4 \%$ of newly diagnosed adult tumors. Over the past 2 decades, RCC has been better characterized clinically and molecularly. It is a heterogeneous disease, with multiple subtypes, each with characteristic histology, genetics, molecular profiles, and biologic behavior. Tremendous heterogeneity has been identified with many distinct subtypes characterized. There are clinical questions to be addressed at every stage of this disease, and new targets being identified for therapeutic development. The unique characteristics of the clinical presentations of RCC have led to both questions and opportunities for improvement in management. Advances in targeted drug development and understanding of immunologic control of RCC are leading to a number of new clinical trials and regimens for advanced disease, with the goal of achieving long-term disease-free survival, as has been achieved in a proportion of such patients historically. RCC management is a promising area of ongoing clinical investigation.
\end{abstract}

\section{INTRODUCTION}

Renal cell cancer (RCC) (epithelial carcinoma of the kidney) represents $2 \%-4 \%$ of newly diagnosed adult tumors. ${ }^{1}$ Prior to the widespread use of tomographic imaging for a variety of diagnostic concerns, RCC was frequently diagnosed in advanced stage. The classic presentation was described as flank/back pain, abdominal mass and/or hematuria. Patients often presented with systemic symptoms of fever, night sweats, weight loss, as well as anemia and hypercalcemia, all of which may still occur as part of the clinical syndrome, either initially, or as the disease progresses. These features continue to predict a poorer outcome, even with modern therapy. An increase in incidence of RCC in part reflects widely available advanced imaging techniques used for other complaints with incidental diagnosis of a renal mass, often described as a small renal mass.

Over the past 2 decades, RCC has been better characterized clinically and molecularly. It is a heterogeneous disease, with multiple subtypes, each with characteristic histology, genetics, molecular profiles, and biologic behavior. Some of these characterizations, particularly for clear cell RCC, the most common subtype, have led to the development of new therapies directed at specific biologic targets, including vascular endothelial growth factor (VEGF) and mammalian target of rapamycin (mTOR). Advances in understanding the immune cellular response to pathogens and tumors have led to efforts to enhance the previously known susceptibility of some RCCs to immunotherapy. In addition to cytokines that stimulate T-cell response against tumors, the role of inhibition of T-cell checkpoints, leading to continued T-cell response, is now integrated into the therapeutic armamentarium. Treatments for the less common subtypes of RCC remain less satisfactory. All of these developments have improved the outcome for many patients with RCC, but have also led to new dilemmas, which will be discussed subsequently. These include (A) the optimal management of small renal masses-are we overtreating?; (B) benefits of sequential versus combination therapies with the new agents; (C) how to enhance the complete response (CR) rate, which has translated to long-term survival in patients treated with cytokines, particularly interleukin (IL)-2; and (D) whether there is an adjuvant treatment approach that translates into survival benefit. Improved pathologic and molecular characterization of RCC subtypes may identify specific new therapeutic targets and lead to more specific and effective interventions.

\section{HETEROGENEITY OF RENAL CANCER}

RCC subtypes are defined by WHO criteria, established in 2004. ${ }^{2}$ This classification system has recently been re-evaluated and updated, with a foundation based on the Vancouver consensus conference of the International Society of Urological Pathology and the WHO consensus meeting. ${ }^{3}{ }^{4}$ This classification system has led to the 2016 WHO classification of tumors of the urinary system and male genital organs ${ }^{5}$ which takes into account substantial new knowledge regarding pathology, epidemiology and molecular genetics ${ }^{56}$ (table 1).

There is increasing awareness of the complexity of clear cell RCC (75\% of cases), with multiple molecular profiles identified ${ }^{6-9}$ and ongoing efforts to identify the biologic significance of the different expression patterns. ${ }^{9}$ Sporadic clear cell RCC is associated with the loss of function of the von HippelLindau $(v H L)$ gene, a tumor suppressor gene, 


\begin{tabular}{|c|c|c|}
\hline Subtype & Clinical features & Molecular/biologic \\
\hline \multicolumn{3}{|l|}{ Major subtypes } \\
\hline Clear cell & $75 \%$ of RCC - heterogeneous biologic behavior & Loss of $v H L$ in the majority \\
\hline Papillary type I & Slow growing/less likely to metastasize & MET alterations; chromosomal gains \\
\hline Papillary type II & $\begin{array}{l}\text { Often aggressive course, but some oncocytic; multiple } \\
\text { molecular entities }\end{array}$ & $\begin{array}{l}3 \text { molecular entities: CDKN2A silencing; SETD2, BAP1, PBRM1 } \\
\text { mutations; increased NRF2-antioxidant response pathway; CIMP } \\
\text { phenotype-FH mutation—see below; TFE3 fusions—see below }\end{array}$ \\
\hline Chromophobe & $\begin{array}{l}\text { Indolent; rare metastases, but if so, often liver, often } \\
\text { oligometastases }\end{array}$ & Impairment of gamma-glutamyltransferase 1 activity \\
\hline Translocation & $\begin{array}{l}\text { Pediatric; young adults; } 40 \% \text { lymph node involvement; range } \\
\text { of intermediate to poor risk }\end{array}$ & $\begin{array}{l}\text { MiT family translocations; previously } t(6 ; 11) \text {; Xp11; nuclear TFE3 } \\
\text { fusions }\end{array}$ \\
\hline Medullary & Sickle trait; aggressive, widely metastatic; chemotherapy & Loss of SMARCB1 (chromatin remodeler and tumor suppressor) \\
\hline Collecting duct & Aggressive; chemotherapy, some targeted therapies & $\begin{array}{l}\text { IHC- PAX8 and integrase interactor-1 (INI-1); unique transcriptomic } \\
\text { profile-metabolic shift—impaired oxidoreductase activity, } \\
\text { pyruvate metabolism, and TCA cycle }\end{array}$ \\
\hline \multicolumn{3}{|c|}{2016 New classifications } \\
\hline HLRCC & Hereditary/poor prognosis & Fumarate hydratase mutation \\
\hline SDH deficient & Hereditary/young adults & $\begin{array}{l}\text { Succinate dehydrogenase deficient-dysfunction of mitochondrial } \\
\text { complex II }\end{array}$ \\
\hline Tubulocystic & $\begin{array}{l}\text { Indolent/oncocytoma-like; very rarely metastatic; present at } \\
\text { lower grade and stage }\end{array}$ & $\begin{array}{l}\text { Downregulated non-coding miRNA expressions compared with } \\
\text { papillary; ongoing research }\end{array}$ \\
\hline Acquired cystic & $\begin{array}{l}\text { Often indolent; arise in ESRD; calcium oxalate crystal } \\
\text { deposition common }\end{array}$ & Fewer unfavorable pathological features than other RCCs \\
\hline Clear cell papillary & Low-grade clear cells arranged in papillae & $\begin{array}{l}\text { Coexpression of CA9, HIF-1 } \alpha \text {, GLUT-1; absence of } v H L \text { gene } \\
\text { alterations }\end{array}$ \\
\hline
\end{tabular}

References 3-39, 124-129.

CA9, carbonic anhydrase-9; ESRD, end-stage renal disease; HIF, hypoxia inducible factor; HLRCC, hereditary leiomyomatosis and RCC syndrome-associated RCC; IHC, immunohistochemistry; RCC, renal cell carcinoma; SDH, succinate dehydrogenase-deficient RCC; TCA, tricarboxylic acid; $v H L$, von Hippel-Lindau.

and is characterized by neoangiogenesis with upregulation of hypoxia-inducible factors. These alterations in function demonstrate the role of VEGF in facilitating renal tumor growth and angiogenesis. ${ }^{10} 11$ These studies have led to extensive therapeutic development of anti-VEGF and antimTOR agents as potential treatment for RCC and other tumors, with now 9 agents in these classes approved for treatment of advanced/metastatic RCC.

Papillary RCC is divided into type I (MET alterations) and type II (at least 3 different molecular entities demonstrated). Additionally, they exhibit different clinical characteristics, with type I being less aggressive and less likely to develop metastases. ${ }^{12}$ Recent evidence suggests that type II may be further subdivided, but distinct, reproducible criteria are not yet fully developed. ${ }^{13}$

Chromophobe RCC is identified by a distinct morphology and molecular profile. This subtype of RCC is usually considered an indolent subtype, with less risk of metastasis. However, if metastasis does occur, surgical resection may be the initial treatment of choice.

Translocation RCC (now categorized as MiT family translocation) was initially identified in pediatric renal tumors, but is now recognized in adults, usually younger adults. ${ }^{14-17}$ Although there are distinct genetic translocations leading to gene fusions coding for transcription factors, this is not considered a hereditary tumor. The prognosis may be reasonably good in children if surgery can render them disease free, but if the disease becomes metastatic, it behaves similarly to that in adults, with poorer outcome.

Medullary RCC is a distinct histologic entity and is a component of renal disorders associated with sickle cell trait. ${ }^{18-20}$ It is usually associated with widespread metastatic disease at presentation and the prognosis is poor. ${ }^{1921}$

Collecting duct carcinoma is considered a renal tumor distinct from urothelial tumors of the renal pelvis. It is an aggressive histology, similar to medullary RCC, and has a poor prognosis. Both chemotherapy and targeted therapies have been employed in both medullary and collecting duct RCC, but with limited benefit.

The 2016 WHO Classification of RCC has established 5 new renal tumor subtypes that were previously considered potential emerging entities. ${ }^{245}$ This change is based on additional molecular and clinical evaluations and pathological data that justify the recognition of these as distinct entities. These 5 new classifications are (A) hereditary leiomyomatosis and RCC syndrome-associated RCC (HLRCC) 2223 ; (B) succinate dehydrogenase-deficient RCC (SDH deficient) ${ }^{2425}$; (C) tubulocystic $\mathrm{RCC}^{26-29}$; (D) acquired cystic disease-associated $\mathrm{RCC}^{30}$; and (E) clear cell papillary RCC. ${ }^{31} 32$

The first 2, HLRCC (previously hereditary type II papillary RCC) and SDH deficient, are among the hereditary RCC syndromes. The cystic tumors demonstrate a unique natural history, in that current reports describe an indolent course. In clinical reports of tubulocystic RCC, only 4 of 70 have developed metastatic disease. A subsequent clinical report, not specifying precise cystic pattern, describes cystic RCC as carrying an excellent prognosis, regardless of tumor size. ${ }^{33}$ Additionally, the 2016 WHO Classification has reclassified multilocular cystic RCC now as 'multilocular cystic renal neoplasm of low malignant potential'. The final new entity, clear cell papillary RCC, accounted for only $5 \%$ of all resected renal tumors. ${ }^{3132}$ 
Additional hereditary RCC syndromes, with distinct clinical characteristics, are associated with morphologically defined subtypes of RCC, including clear cell (vHL syndrome-benign and malignant bilateral small renal tumors, hemangioblastomas of brain and spine, retinal angiomas, other sites), ${ }^{10}{ }^{34}$ familial type I papillary RCC (germline mutation of c-met proto-oncogene, bilateral renal tumors), ${ }^{3536}$ and cystic and chromophobe histologies (Birt-Hogg-Dube syndrome-skin fibrofolliculomas, lung cysts, benign renal tumors and RCC). ${ }^{37} 38$ Hereditary RCC syndromes account for 3\%-5\% of RCC, and other inherited syndromes exist that include an increased risk of RCC. ${ }^{39}$

\section{SURGICAL MANAGEMENT ISSUES Maintaining renal function}

Over the past 2 decades, surgical approaches have evolved, coincident with the more frequent diagnosis of smaller renal masses, particularly $\leq 7 \mathrm{~cm}$. Techniques have been developed to accomplish partial nephrectomies, reducing ischemic time, and with the goal of nephron sparing. Studies have been reported that demonstrate comparable outcomes in terms of long-term disease control, with reduced incidence of chronic renal failure, delayed cardiovascular disease, and improved survival, including long-term survival. ${ }^{40-46}$ Additionally, 1 report describes improved survival following partial nephrectomy compared with radical nephrectomy for tumors inadvertently discovered to be benign. ${ }^{47}$ Current guidelines from the American Society of Clinical Oncology and the Canadian Kidney Cancer Consensus as well as the National Comprehensive Cancer Network, all recommend partial nephrectomy whenever feasible and meeting criteria outlined in their reports. ${ }^{48-50}$ This is particularly applicable to the setting of small renal masses, which will be discussed further. ${ }^{48-52}$

\section{Small renal masses}

As previously discussed, most of the increased incidence of RCC is the radiologic identification of small renal masses. This has led to a dilemma in management with options ranging from active surveillance to ablation procedures to partial nephrectomy. ${ }^{48}{ }^{49}$ Unfortunately, current imaging techniques cannot accurately distinguish benign from malignant tumors in most cases, ${ }^{5354}$ and some series report as much as $20 \%$ of such small tumors being benign at pathologic review. ${ }^{52}$ In addition, contemporary reports confirm the safety of needle biopsies of small masses, and the accuracy of biopsies compared with the final surgical specimen. ${ }^{54}$ As more centers evaluate premanagement biopsy, criteria are evolving to define tumors less likely to have successful diagnostic biopsies. ${ }^{55-57}$ The recently published guidelines regarding small renal masses continue to emphasize the need for accurate diagnosis with recommendations for renal tumor biopsies prior to therapeutic decisions. ${ }^{48} 49$ Criteria for recommendations for active surveillance of small renal masses, and guidelines for the use of ablative techniques versus surgery continue to be refined.

\section{NEPHRECTOMY IN THE SETTING OF METASTATIC DISEASE}

In the early era of cytokine therapy for metastatic RCC, 2 prospective randomized studies demonstrated that nephrectomy contributed to better outcome in the setting of metastatic disease followed by cytokine therapy, compared with interferon alone. ${ }^{5859}$ The role of cytoreductive nephrectomy in the present era of first-line targeted therapies continues to be discussed. Retrospective analyses, including a large meta-analysis (11 studies, 39,000 patients), have all reported the survival benefit of cytoreductive nephrectomy in selected patients. ${ }^{60-62}$ All of these reports have identified cytoreductive nephrectomy as an independent factor in multivariate analyses, conferring a survival advantage. ${ }^{60-62}$

Experience-based clinical judgement is the most productive approach to decision-making in this setting. The decision for nephrectomy is usually made based on the bulk and distribution of the tumor, as well as tumor-related symptoms, and pace of disease. If the greatest amount of tumor is in the kidney, with limited volume metastatic disease, then nephrectomy may indeed confer improved outcome, both in terms of reducing localized symptoms, and in long-term outcome. ${ }^{58-62}$

\section{MANAGEMENT OF ADVANCED RCC}

Despite the increased detection of small renal masses of variable clinical significance, $25 \%-30 \%$ of patients with RCC present with metastatic disease. This is often identified by imaging for unassociated complaints, but also for symptomatic, previously undetected disease. These are settings in which cytoreductive nephrectomy could be considered, depending on the extent and locations of all sites of disease. Another group of stage IV patients are those who recur with advanced disease, having been disease free months to years after the initial diagnosis and nephrectomy. The time to recurrence remains a major prognostic factor for outcome with systemic treatment, whether immunotherapy or targeted therapy.

\section{CLINICAL FEATURES OF METASTATIC RCC: PREDICTIVE RISK CRITERIA}

In addition to characteristics noted in molecularly defined subtypes of RCC, advanced RCC has distinct clinical features: (A) the contrast of patients with oligometastatic disease (ie, only 1 or 2 sites) versus patients with extensive disease in multiple sites; (B) metastatic disease synchronous with the renal tumor versus metachronous; and (C) clinical signs and symptoms versus no symptoms. These characteristics have led over time to the development of prognostic criteria that can be evaluated at the time of metastatic disease, and define differing survival outcomes. Box 1 demonstrates the current most commonly used risk criteria and the risk category outcome. ${ }^{6364}$

The favorable risk group is characterized by more slowly progressing disease, and some patients may not require treatment initially, particularly if there are clinical comorbidities which could be exacerbated by treatment-related toxicities, or in a patient with no symptoms. These patients may be evaluated based on serial scans before a treatment decision is made. This slowly progressing category may also include papillary type I or chromophobe RCC (in which metastatic disease is rare, but when present is often very indolent) and surgery may also be the optimal initial decision. Again, serial scans to identify the pace of disease help reduce and postpone 
Box 1 IMDC prognostic risk criteria for reduced survival and outcome by risk group ${ }^{63} 64$

Risk factors for reduced survival

1. Eastern Cooperative Oncology Group (ECOG) performance status* (PS) $>1$; Karnofsky† PS $<80 \%$.

2. Time from diagnosis to systemic treatment $<1$ year.

3. Hemoglobin <lower limit of normal (LLN).

4. Corrected serum calcium >upper LN (ULN).

5. Neutrophil count $>$ ULN.

6. Platelet count $>$ ULN.

IMDC risk categories and median survival outcomes

1. Favorable-no adverse risk factors; median survival: not reached; 2 -year survival $75 \%$.

2. Intermediate-1-2 risk factors; median survival: 27 months; 2 -year survival $53 \%$.

3. Poor $\geq 3$ risk factors; median survival: 8.8 months; 2 -year survival $7 \%$.

*ECOG PS $0=$ fully functional, with PS 1 =symptoms, but functional; PS 2-5 further limitations, through 5 (death).

†Karnofsky PS $100 \%$ =fully functional, with percentage declines by $10 \%$ increments.

IMDC, International Metastatic Renal Cell Carcinoma Database Consortium.

treatment-related toxicity until systemic treatment is absolutely necessary.

The converse is in the patient group with aggressive disease that is rapidly growing. This entity generally is in the poor risk group and/or the aggressive histologic subtypes. In general, these patients are treated with targeted therapy (clear cell and papillary) or with chemotherapy (medullary and collecting duct) but their outcome remains poor.

The majority (more than 50\%) of patients with advanced RCC fall into the intermediate risk group, based on clinical characteristics. Continued evaluation of molecular characteristics will hopefully identify new targets and guide therapeutic development. Currently, these patients are treated on diagnosis.

These risk criteria have been predictive of survival, regardless of type of therapy, including cytokines, antiVEGF agents and more recently, checkpoint inhibitory (CPI) immunotherapy. ${ }^{6364}$ Clinical interventions may differ also, depending on the clinical features and the risk categories. For example, many centers advocate localized treatment of oligometastatic disease with close follow-up or localized treatment. ${ }^{6566}$

\section{SITES OF METASTATIC DISEASE: SPECIAL CONSIDERATION OF BONE AND BRAIN METASTASES}

RCC is noted for hematogenous metastasis, and as such the most common site of metastatic disease is the lung, followed by bone, liver and brain. ${ }^{67}$ That being said, unusual sites of disease are also noted, such as endobronchial, soft tissue, and cutaneous lesions, as well as mucosal gastrointestinal nodules. However, regional lymph node involvement is not uncommon, and is characteristic of certain subtypes of RCC, such as translocation subgroups and papillary type I.
Lung nodules are often asymptomatic, even when multiple, and seem to be quite responsive to systemic therapy. These are the most easily monitored sites of disease. Similarly, soft tissue nodules are often responsive to systemic therapy, but liver lesions are variable in response. Other sites of disease may be more problematic, requiring multimodality interventions. Although RCC has been considered a radiation-resistant tumor, the development of stereotactic body radiotherapy (SBRT) has improved outcomes for treatment of specific metastases, particularly in bone or brain, while limiting local toxicity.

Bone metastases are present in one-third of patients at diagnosis of metastatic disease, and develop subsequently in another one-third. ${ }^{68}$ Metastatic bone disease presents a unique clinical problem, by its frequency, its distribution, and the potential for development of pain and serious complications. It is a major cause of morbidity and mortality in metastatic RCC and remains difficult to manage. There is a predilection for flat bones, such as pelvis and scapula, as well as proximal long bones and spine. Additionally, because the majority of these lesions are osteolytic, bone involvement is rarely detected by bone scan imaging.

The concern for the unique behavior of and limited treatment options for bone metastases from renal cell carcinoma has led to the convening of an interdisciplinary consensus conference on management that was recently published. ${ }^{69}$ This group reviewed the literature and provided summaries of clinical evidence and then presented their consensus and recommendations, as well as identification of unmet needs. This group addressed epidemiology, diagnostic evaluations and imaging, local therapies for RCC bone metastasesincluding surgery, radiotherapy techniques and thermal ablation, as well as medical therapies-both antitumor and bone-targeting agents.

Brain metastases are characteristic of RCC, both on diagnosis of metastatic disease, and subsequently. The frequency of brain metastases is increased in patients with RCC who have thoracic metastases. ${ }^{67}$ Clinical guidelines recommend brain imaging part of the initial evaluation of a suspicious renal mass. ${ }^{70}$ Brain imaging is also routinely conducted during the course of ongoing systemic treatment and, of course, if neurologic symptoms arise. Brain lesions from RCC can be a cause of catastrophic hemorrhage, so intervention is usually indicated. Therapeutic recommendations are dependent on the overall status of the disease process and the extent of brain involvement. However, solitary brain metastases can be successfully treated with surgical resection or SBRT in appropriate patients, with sometimes prolonged overall survival (OS). ${ }^{7172}$ Encouraging recent reports suggest response of brain metastases to systemic therapy with anti-VEGF targeted therapies or CPI immunotherapy, in particular when combined with resection or stereotactic radiation. ${ }^{73-77}$ Additional studies are ongoing.

\section{SYSTEMIC TREATMENT STRATEGIES}

Systemic treatment approaches have developed primarily in managing clear cell RCC. Resistance to chemotherapy was well demonstrated in multiple early trials. However, anecdotes of spontaneous regression of metastases after 


\begin{tabular}{ll}
\hline $\begin{array}{l}\text { Table 2A Approved systemic therapies for metastatic renal cell } \\
\text { carcinoma }\end{array}$ & Approval date \\
\hline Agent & \\
\hline Cytokines & 1980 s \\
\hline Interferon-alpha & 2009 -with bevacizumab \\
\hline Interleukin-2 & 1992 \\
\hline Anti-VEGF agents & \\
\hline Sorafenib & December 2005 \\
\hline Sunitinib & January 2006 \\
\hline Bevacizumab+interferon & 2009 \\
\hline Pazopanib & 2009 \\
\hline Axitinib & 2012 \\
\hline Anti-mTOR agents & \\
\hline Temsirolimus & 2007 \\
\hline Everolimus & 2009 \\
\hline Everolimus+lenvatinib & 2016 \\
\hline Multitarget anti-VEGF & \\
\hline Cabozantinib & 2016 \\
\hline Lenvatinib+everolimus & 2016 \\
\hline Checkpoint inhibitors & 2015 \\
\hline Nivolumab & 2018 \\
\hline Nivolumab+ipilimumab & Breakthrough status 2018 \\
\hline Pembrolizumab+lenvatinib & 504 endothel growth \\
\hline
\end{tabular}

mTOR, mammalian target of rapamycin; VEGF, vascular endothelial growth factor.

cytoreductive nephrectomy led to treatment with interferon as immune-stimulatory therapy. Responses to interferon were reported, some quite durable, including CRs. ${ }^{78} 79 \mathrm{In}$ 1992, IL-2, T-cell growth factor, was approved for treatment of metastatic RCC based on CRs and durable responses. ${ }^{80} 81$ Clinical studies have defined patients with RCC likely to respond to IL-2 as having clear cell histology and excellent performance status. ${ }^{80} 81$ In subsequent and contemporary follow-up of patients undergoing this treatment, decadelong disease-free and treatment-free survivors are reported. ${ }^{82-87} \mathrm{~A}$ recent report describes the clinical benefit (complete response + partial response + stable disease$\mathrm{CR}+\mathrm{PR}+\mathrm{SD}$ ) and $\mathrm{OS}$ for patients treated with IL-2, according to clinical risk groups. ${ }^{64}$ For patients treated with IL-2 only, the favorable risk group had a clinical benefit rate of $76 \%$ and a median OS of greater than 5 years. The intermediate risk group had a clinical benefit rate of $49 \%$ and a median OS of greater than 4.5 years. ${ }^{87} \mathrm{IL}-2$ continues to be an important option for appropriate patients, and demonstrates the therapeutic goal for advanced RCC: to achieve long-term, disease and treatment-free survival (table 2A,B).

As a growing understanding of RCC biology became evident, the important role of $v H L$ gene loss of function in RCC tumor growth and metastasis was defined. ${ }^{10}{ }^{11}$ This loss of function leading to aberrant angiogenesis explained the highly vascular features of RCC, and in part the efficacy of interferon, antiangiogenesis in addition to enhanced immunologic activity. ${ }^{88}$ Impeding angiogenesis became a therapeutic goal, leading to development of a number of anti-VEGF and anti-mTOR agents, as well as identifying other targets for evaluation. Since December 2005, nine targeted agents have been approved to date for RCC, based on randomized trials demonstrating incremental improvement in progression-free survival (PFS) and some in survival. Five agents are directed primarily toward VEGF, 2 directed toward mTOR, and 2 with strong inhibition of targets in addition to VEGF. ${ }^{89-98}$ The development of these targeted therapies has provided clinical benefit to increasing numbers of patients with advanced RCC. The availability of these agents provides opportunities for investigation of sequential and combination treatment approaches.

Contemporaneously, improved understanding of T-cell biology has defined the role of numerous immune checkpoints in curbing immune responses to prevent autoimmunity, but simultaneously allowing tumor growth escape. ${ }^{99} 100$ This understanding has led to the development of immune checkpoint inhibitors (CPI), designed to 'remove the brake' on immune activation against tumors. ${ }^{101} 102$ The importance of the identification of these mechanisms and their clinical relevance has led to the awarding of the 2018 Nobel Prize in Medicine to Dr James Allison and Dr Tasuku Honjo for their exposition of mechanisms of cytotoxic T-cell lymphocyte-associated antigen-4 (CTLA-4) and programmed death 1/ligand (PD-1/PD-L1) in checking immune response, particularly focused on tumors. ${ }^{99}{ }^{100}$ These 2 checkpoints are the first in which antibodies have been developed to curb their activity, demonstrating enhanced immune response and clear antitumor activity in humans. ${ }^{103104}$ Subsequently, both categories of CPI have been approved for treatment of multiple tumor types, including RCC. These agents continue to be evaluated as monotherapy and in combination with other immunotherapies (approved and investigational) and with anti-VEGF agents (NCT02231749, NCT02320821, NCT02682006, NCT02853331, NCT03141177, NCT02811861). ${ }^{105-107}$ The anti-PD-1 agent nivolumab has recently been approved in combination with the anti-CTLA-4 agent ipilimumab for advanced RCC, ${ }^{108}$ and the combination of pembrolizumab (anti-PD-1) with lenvatinib (anti-VEGF) has been given breakthrough designation for metastatic RCC in ongoing evaluation, based on initial reports from a broad phase 2 study in patients with solid tumor (NCT02501096). Inhibitors of other immune checkpoints are also undergoing clinical investigation in multiple tumor types including RCC (NCT01968109).

Table 2A lists the approved agents for systemic treatment, and their approval dates. Of note, combinations are entering the clinical armamentarium. Table 2B is adapted from the September 2018 NCCN Guidelines ${ }^{70}$ and addresses both clear cell RCC and non-clear cell RCC. Of note, all approved drugs are listed, and sequence reflects the type of study that led to approval. All approved drugs are recommended for treatment of metastatic RCC.

The development and approval of so many drugs with activity in RCC has provided empiric data on sequential treatment of the same or different mechanisms of actions, but no clear recommendation has yet emerged. Therapeutic decisions are currently based on clinical factors and condition of the patients. Responders to initial immunotherapy may again respond to subsequent immunotherapy, but that observation is not yet fully evaluated. Evaluation of the potential sequential interactions of anti-VEGF therapy and immunotherapy is ongoing. ${ }^{109}$ 
Table 2B NCCN Clinical Guidelines—systemic therapy relapsed/stage IV RCC—September 2018

\begin{tabular}{|c|c|}
\hline \multicolumn{2}{|l|}{ Clear cell RCC—first-line therapy } \\
\hline \multicolumn{2}{|l|}{ Clear cell RCC_favorable risk } \\
\hline Preferred & $\begin{array}{l}\text { Sunitinib } \\
\text { Pazopanib }\end{array}$ \\
\hline Other recommended & $\begin{array}{l}\text { Ipilimumab+nivolumab } \\
\text { Cabozantinib }\end{array}$ \\
\hline Useful in certain circumstances & $\begin{array}{l}\text { Active surveillance } \\
\text { Axitinib } \\
\text { Bevacizumab+interferon-alpha-2b } \\
\text { High-dose interleukin-2 }\end{array}$ \\
\hline \multicolumn{2}{|l|}{ Clear cell RCC—poor/intermediate risk } \\
\hline Preferred & $\begin{array}{l}\text { Ipilimumab+nivolumab } \\
\text { Cabozantinib }\end{array}$ \\
\hline Other recommended & $\begin{array}{l}\text { Pazopanib } \\
\text { Sunitinib }\end{array}$ \\
\hline Useful in certain circumstances & $\begin{array}{l}\text { Axitinib } \\
\text { Bevacizumab+interferon-alpha-2b } \\
\text { High-dose interleukin-2 } \\
\text { Temsirolimus }\end{array}$ \\
\hline \multicolumn{2}{|c|}{ Clear cell RCC-therapy subsequent to progression after first-line therapy } \\
\hline Preferred & $\begin{array}{l}\text { Cabozantinib } \\
\text { Nivolumab } \\
\text { Ipilimumab+nivolumab }\end{array}$ \\
\hline Other recommended & $\begin{array}{l}\text { Axitinib } \\
\text { Lenvatinib+everolimus } \\
\text { Everolimus } \\
\text { Pazopanib } \\
\text { Sunitinib }\end{array}$ \\
\hline Useful in certain circumstances & $\begin{array}{l}\text { Bevacizumab } \\
\text { Sorafenib } \\
\text { High-dose interleukin-2—-selected patients } \\
\text { Temsirolimus }\end{array}$ \\
\hline \multicolumn{2}{|l|}{ Non-clear cell RCC } \\
\hline Preferred & $\begin{array}{l}\text { Clinical trial } \\
\text { Sunitinib }\end{array}$ \\
\hline Other recommended & $\begin{array}{l}\text { Cabozantinib } \\
\text { Everolimus }\end{array}$ \\
\hline Useful under certain circumstances & $\begin{array}{l}\text { Axitinib } \\
\text { Bevacizumab } \\
\text { Erlotinib } \\
\text { Lenvatinib+everolimus } \\
\text { Nivolumab } \\
\text { Pazopanib } \\
\text { Bevacizumab+erlotinib for selected patients with advanced papillary RCC } \\
\text { including HLRCC } \\
\text { Bevacizumab+everolimus } \\
\text { Temsirolimus }\end{array}$ \\
\hline
\end{tabular}

Adapted from NCCN Clinical Practice Guidelines in Oncology ${ }^{70}$, version 2.2019; 9/17/18.

HLRCC, hereditary leiomyomatosis and RCC syndrome-associated RCC; RCC, renal cell cancer.

\section{MANAGEMENT OF NON-CLEAR CELL RCC}

Non-clear cell RCC comprises a minority of cases of advanced RCC and treatment options have generally followed those of clear cell RCC, but with less success. ${ }^{110}$ However, non-clear cell RCC consists of a number of histologically and molecularly distinct subtypes as previously noted (table 1). Most data on outcomes of treatment of non-clear cell RCC consist of small reports, but recently clinical trials directed specifically at non-clear cell RCC have begun, studying the array of drugs available for RCC, as well as drugs directed at other targets. ${ }^{110}$ Papillary type I is the most common of the non-clear cell subtypes, and may harbor MET mutations, and investigation of agents directed toward this target is in progress. Among the anti-VEGF agents, cabozantinib targets MET and additional anti-MET agents are undergoing study. ${ }^{96111}$

Rapidly progressive subtypes, such as medullary and collecting duct RCC, have traditionally been treated with cisplatin-based chemotherapy due to the high percentage of cells in cycle. They are poorly responsive to antiVEGF therapy. ${ }^{112}$ A recent consensus conference evaluated the diagnosis and management of renal medullary 
carcinoma, and continues to recommend cisplatin-based chemotherapy but with earlier administration in the course of the disease, since the tumor is so aggressive. ${ }^{113}$

Other considerations for non-clear cell RCC are the checkpoint inhibitors which have a broad base of antitumor activity, including in tumors with multiple mutations, but whether this will apply to non-clear cell RCC is yet to be clarified. The availability of a larger menu of anti-RCC agents as well as continued improved understanding of molecular drivers will hopefully lead to better treatment options for patients with non-clear cell RCC. ${ }^{110} 112$

\section{ADJUVANT THERAPY}

Adjuvant therapy is the treatment of anticipated, but not observed, microscopic residual disease following surgical removal of all visible tumors, that is, following nephrectomy in the case of RCC. ${ }^{114}$ While this approach has proven effective in a number of tumor types, for example, breast and colorectal, it is yet to be proven effective in RCC at high risk for recurrence. Several large prospective randomized clinical trials of anti-VEGF therapy compared with placebo in patients with RCC with risk for recurrence have not shown PFS or survival benefit, ${ }^{115-117}$ while 1 trial reported PFS benefit but not a benefit for OS. ${ }^{118}$ However, this observation has led to approval of sunitinib as adjuvant treatment for high-risk resected RCC. Further analysis of a similar high-risk population within the initial cooperative group trial still failed to demonstrate a benefit of therapy over placebo. ${ }^{115} 119$ Attempts to sort out the differences between trials which may account for the different reported results include evaluation of dose intensity and level of drug exposure, subgroup analyses and, recently, immunologic parameters such as PD-L1 expression and CD8+ T-cell infiltration as predictive of benefit in the positive trial. ${ }^{120-122}$ It is gratifying that this degree of analysis is ongoing, but it remains that making a recommendation regarding adjuvant anti-VEGF therapy outside of a clinical trial is controversial, and risk/benefit ratio continues to be the major discussion.

Three additional adjuvant trials of targeted therapy (NCT00492258, NCT01120249, NCT01575548) and 4 of PD-1 pathway directed therapies (NCT03138512, NCT03024996, NCT03242224, NCT03055013) are ongoing. Additionally, a study has reported the validation of a 16-gene recurrence score for RCC using the subjects of the S-TRAC trial. ${ }^{123}$ This will likely be evaluated in all ongoing trials in which tissue is available for analysis. There will likely be much further discussion and analysis before a consensus recommendation can be established.

\section{SUMMARY}

Much progress has been made in the treatment of RCC, with the goals of improving outcome for both early stage and advanced disease. Better understanding of molecular profiles and antitumor immunity has led to new therapies that have greatly changed the clinical landscape, and benefited many patients. This has also led to many new challenges to optimize treatment approaches. Questions remain in management of early stage disease to minimize late-onset complications; to improve treatment for difficult sites of metastatic disease; to optimally manage and sequence treatment of systemic disease; and to better define treatment for all subsets of RCC. Ongoing evaluation of recurrence risk and molecular profiling may further direct therapy of larger populations of patients with RCC.

\section{GOAL OF MANAGEMENT OF METASTATIC RCC}

IL-2 therapy, a T-cell growth factor, is the early immunotherapy which has achieved significant numbers of patients with metastatic RCC having decades-long disease-free survival, possibly cures, following treatment, which is almost unique among advanced adult solid tumors. ${ }^{82-87}$ These patients include subjects in both favorable and intermediate risk categories and those with clinical benefit after treatment $(\mathrm{CR}+\mathrm{PR}+\mathrm{SD})$ but particularly $\mathrm{CR}+\mathrm{PR} .{ }^{87}$ Therefore, the goal of all new clinical trials and particularly combination regimens should be to enhance the percentage of patients who achieve durable response and prolonged survival, preferably off-therapy. Numerous studies of various immunotherapy agents combined with other immunotherapy, including new checkpoint inhibitors, as well as with localized radiation, or with targeted therapies are ongoing, with the goal of yielding additive or synergistic benefits.

Acknowledgements Thanks to Peter H Wiernik for his careful review of this manuscript.

Contributors JPD designed and researched and wrote this manuscript.

Funding The authors have not declared a specific grant for this research from any funding agency in the public, commercial or not-for-profit sectors.

Competing interests JPD is a consultant for Prometheus Laboratories; a member of data safety and monitoring committees for BMS, Eisai, Tracon, Merck, Amgen, lovance, and PrECOG. JPD is a medical oncology cochair of the Renal Task Force, CTEP, NCl.

Patient consent Not required.

Provenance and peer review Commissioned; externally peer reviewed.

\section{REFERENCES}

1 Siegel R, Naishadham D, Jemal A. Cancer statistics, 2013. CA Cancer J Clin 2013:63:11-30.

2 Eble JN, Sauter G, Epstein Jl, et al. World Health Organization Classification of Tumours. Pathology and Genetics of Tumours of the Urinary System and Male Genital Organs. Lyon, France: IARC Press, 2004.

3 Srigley JR, Delahunt B, Eble JN, et al. The International Society of Urological Pathology (ISUP) Vancouver Classification of Renal Neoplasia. Am J Surg Pathol 2013;37:1469-89.

4 Moch H, Humphrey PA, Ulbright TM, et al. WHO Classification of Tumours of the Urinary System and Male Genital Organs. Lyon, France: International Agency for Research on Cancer, 2016.

5 Moch H, Cubilla AL, Humphrey PA, et al. The 2016 WHO Classification of Tumours of the Urinary System and Male Genital Organs_-Part A: Renal, Penile, and Testicular Tumours. Eur Urol 2016;70:93-105.

6 Frew IJ, Moch H. A clearer view of the molecular complexity of clear cell renal cell carcinoma. Annu Rev Pathol 2015;10:263-89.

7 Cheville JC, Lohse CM, Zincke $\mathrm{H}$, et al. Comparisons of outcome and prognostic features among histologic subtypes of renal cell carcinoma. Am J Surg Pathol 2003;27:612-24.

8 Takahashi M, Teh BT, Kanayama HO. Elucidation of the molecular signatures of renal cell carcinoma by gene expression profiling. J Med Invest 2006:53:9-19.

9 Haake S, Brannon A, Hacker K, et al. Use of meta-analysis of clear cell renal cell carcinoma gene expression to define a variant subgroup and identify gender issues on tumor biology. J Clin Oncol 2013;30. abst 412.

10 Kaelin WG. The von Hippel-Lindau tumor suppressor protein and clear cell renal carcinoma. Clin Cancer Res 2007;13:680s-4.

11 Kaelin Jr W. Molecular Biology of Kidney Cancer. In: Lara Jr P, Jonash E, eds. Kidney Cancer: principles and practice. Berlin: Springer, 2012:29-46.

12 Delahunt B, Eble JN, McCredie MR, et al. Morphologic typing of papillary renal cell carcinoma: comparison of growth kinetics and patient survival in 66 cases. Hum Pathol 2001:32:590-5. 
13 Linehan WM, Spellman PT, Ricketts CJ, et al. Comprehensive molecular characterization of papillary renal-cell carcinoma. N Engl J Med 2016;374:135-45

14 Argani $\mathrm{P}$, Lal $\mathrm{P}$, Hutchinson $\mathrm{B}$, et al. Aberrant nuclear immunoreactivity for TFE3 in neoplasms with TFE3 gene fusions: a sensitive and specific immunohistochemical assay. Am J Surg Pathol 2003;27:750-61.

15 Geller J, Mullen E, Khanna G, et al. Epidemiology and characterization of pediatric and adolescent renal cell carcinoma: A report from the Children's Oncology Group Study AREN 03B2. Br J Urol Int 2012;110:18-19. Abst 40.

16 Malouf GG, Camparo P, Oudard S, et al. Targeted agents in metastatic Xp11 translocation/TFE3 gene fusion renal cell carcinoma (RCC): a report from the Juvenile RCC Network. Ann Oncol 2010;21:1834-8.

17 Malouf G, Camparo P, Molinie V, et al. TFE3 and TFEB renal cell carcinomas: Clinical features, biological behavior and prognostic features. J Urol 2011;185:24-9.

18 Davis CJ, Mostofi FK, Sesterhenn IA. Renal medullary carcinoma. The seventh sickle cell nephropathy. Am J Surg Pathol 1995;19:1-11.

19 Swartz MA, Karth J, Schneider DT, et al. Renal medullary carcinoma: clinical, pathologic, immunohistochemical, and genetic analysis with pathogenetic implications. Urology 2002;60:1083-9.

20 Yang XJ, Sugimura J, Tretiakova MS, et al. Gene expression profiling of renal medullary carcinoma: potential clinical relevance. Cancer 2004;100:976-85.

21 Hakimi AA, Koi PT, Milhoua PM, et al. Renal medullary carcinoma: the Bronx experience. Urology 2007;70:878-82.

22 Tomlinson IP, Alam NA, Rowan AJ, et al. Germline mutations in FH predispose to dominantly inherited uterine fibroids, skin leiomyomata and papillary renal cell cancer. Nat Genet 2002;30:406-10.

23 Merino MJ, Torres-Cabala C, Pinto P, et al. The morphologic spectrum of kidney tumors in hereditary leiomyomatosis and renal cell carcinoma (HLRCC) syndrome. Am J Surg Pathol 2007;31:1578-85.

24 Gill AJ, Hes O, Papathomas T, et al. Succinate dehydrogenase (SDH)deficient renal carcinoma: a morphologically distinct entity: a clinicopathologic series of 36 tumors from 27 patients. Am J Surg Pathol 2014;38:1588-602

25 Ricketts C, Woodward ER, Killick P, et al. Germline SDHB mutations and familial renal cell carcinoma. J Nat/ Cancer Inst 2008;100:1260-2.

26 Zhou M, Yang XJ, Lopez II, et al. Renal tubulocystic carcinoma is closely related to papillary renal cell carcinoma: implications for pathologic classification. Am J Surg Pathol 2009;33:1840-9.

27 Amin MB, MacLennan GT, Gupta R, et al. Tubulocystic carcinoma of the kidney: clinicopathologic analysis of 31 cases of a distinctive rare subtype of renal cell carcinoma. Am J Surg Pathol 2009;33:384-92.

28 Yang XJ, Zhou M, Hes 0 , et al. Tubulocystic carcinoma of the kidney: clinicopathologic and molecular characterization. Am J Surg Pathol 2008;32:177-87.

29 Azoulay S, Vieillefond A, Paraf F, et al. Tubulocystic carcinoma of the kidney: a new entity among renal tumors. Virchows Arch 2007;451:905-9.

30 Tickoo SK, dePeralta-Venturina MN, Harik LR, et al. Spectrum of epithelial neoplasms in end-stage renal disease: an experience from 66 tumor-bearing kidneys with emphasis on histologic patterns distinct from those in sporadic adult renal neoplasia. Am J Surg Pathol 2006;30:141-53.

31 Rohan SM, Xiao Y, Liang Y, et al. Clear-cell papillary renal cell carcinoma: molecular and immunohistochemical analysis with emphasis on the von Hippel-Lindau gene and hypoxia-inducible factor pathway-related proteins. Mod Pathol 2011;24:1207-20.

32 Zhou H, Zheng S, Truong LD, et al. Clear cell papillary renal cell carcinoma is the fourth most common histologic type of renal cell carcinoma in 290 consecutive nephrectomies for renal cell carcinoma. Hum Pathol 2014:45:59-64.

33 Winters BR, Gore JL, Holt SK, et al. Cystic renal cell carcinoma carries an excellent prognosis regardless of tumor size. Urol Oncol 2015;33:505. e9-505.e13.

34 Latif F, Tory K, Gnarra J, et al. Identification of the von Hippel-Lindau disease tumor suppressor gene. Science 1993;260:1317-20.

35 Zbar B, Tory K, Merino M, et al. Hereditary papillary renal cell carcinoma. J Urol 1994;151:561-6.

36 Lubensky IA, Schmidt L, Zhuang Z, et al. Hereditary and sporadic papillary renal carcinomas with c-met mutations share a distinct morphological phenotype. Am J Pathol 1999;155:517-26.

37 Schmidt LS, Warren MB, Nickerson ML, et al. Birt-Hogg-Dubé syndrome, a genodermatosis associated with spontaneous pneumothorax and kidney neoplasia, maps to chromosome 17p11.2. Am J Hum Genet 2001;69:876-82.

38 Pavlovich CP, Walther MM, Eyler RA, et al. Renal tumors in the Birt-HoggDubé syndrome. Am J Surg Pathol 2002;26:1542-52.
39 Haas NB, Nathanson KL. Hereditary renal cancer syndromes. Adv Chronic Kidney Dis 2014211

40 Lau WK, Blute ML, Weaver AL, et al. Matched comparison of radical nephrectomy vs nephron-sparing surgery in patients with unilateral renal cell carcinoma and a normal contralateral kidney. Mayo Clin Proc 2000;75:1236-42

41 Leibovich BC, Blute ML, Cheville JC, et al. Neprhon sparing surgery for appropriately selected renal cell carcinoma between 4 and $7 \mathrm{~cm}$ results in outcome similar to radical nephrectomy. J Urol 2000;163:730-6.

42 Zini L, Perrotte P, Capitanio U, et al. Radical versus partial nephrectomy: effect on overall and noncancer mortality. Cancer 2009;115:1465-71.

43 Lee HJ, Liss MA, Derweesh IH. Outcomes of partial nephrectomy for clinical T1b and T2 renal tumors. Curr Opin Urol 2014;24:448-52.

44 Kim SP, Thompson RH, Boorjian SA, et al. Comparative effectiveness for survival and renal function of partial and radical nephrectomy for localized renal tumors: a systematic review and meta-analysis. J Urol 2012;188:51-7.

45 Tan HJ, Norton EC, Ye Z, et al. Long-term survival following partial vs radical nephrectomy among older patients with early-stage kidney cancer. JAMA 2012;307:1629-35.

46 Touijer K, Jacqmin D, Kavoussi LR, et al. The expanding role of partial nephrectomy: a critical analysis of indications, results, and complications. Eur Urol 2010;57:214-22.

47 Weight CJ, Lieser G, Larson BT, et al. Partial nephrectomy is associated with improved overall survival compared to radical nephrectomy in patients with unanticipated benign renal tumours. Eur Urol 2010;58:293-8.

48 Finelli A, Ismaila N, Bro B, et al. Management of small renal masses: American Society of clinical oncology clinical practice guideline. J Clin Oncol 2017;35:668-80

49 Jewett MA, Rendon R, Lacombe L, et al. Canadian guidelines for the management of small renal masses (SRM). Can Urol Assoc J 2015;9:160-3.

50 Motzer RJ, Jonasch E, Agarwal N, et al. Kidney Cancer, Version 2.2017. J Natl Compr Cancer Netw 2017;15:804-34.

51 Huang WC, Atoria CL, Bjurlin M, et al. Management of small kidney cancers in the new millennium: contemporary trends and outcomes in a populationbased cohort. JAMA Surg 2015;150:664-72.

52 Almassi N, Gill BC, Rini B, et al. Management of the small renal mass. Trans/ Androl Urol 2017:6:923-30.

53 Dechet CB, Zincke H, Sebo TJ, et al. Prospective analysis of computerized tomography and needle biopsy with permanent sectioning to determine the nature of solid renal masses in adults. J Urol 2003;169:71-4.

54 Lane BR, Samplaski MK, Herts BR, et al. Renal mass biopsy--a renaissance? J Urol 2008; 179:20-7.

55 Jeon $\mathrm{HG}$, Seo SI, Jeong BC, et al. Percutaneous kidney biopsy for a small renal mass: a critical appraisal of results. J Urol 2016;195:568-73.

56 Halverson SJ, Kunju LP, Bhalla R, et al. Accuracy of determining small renal mass management with risk stratified biopsies: confirmation by final pathology. J Uro/ 2013;189:441-6.

57 Prince J, Bultman E, Hinshaw L, et al. Patient and tumor characteristics can predict nondiagnostic renal mass biopsy findings. J Urol 2015;193:1899-904.

58 Flanigan RC, Salmon SE, Blumenstein BA, et al. Nephrectomy followed by interferon alfa-2b compared with interferon alfa-2b alone for metastatic renal-cell cancer. N Engl J Med 2001;345:1655-9.

59 Mickisch GH, Garin A, van Poppel H, et al. Radical nephrectomy plus interferon-alfa-based immunotherapy compared with interferon alfa alone in metastatic renal-cell carcinoma: a randomised trial. Lancet 2001;358:966-70

60 Choueiri TK, Xie W, Kollmannsberger C, et al. The impact of cytoreductive nephrectomy on survival of patients with metastatic renal cell carcinoma receiving vascular endothelial growth factor targeted therapy. J Urol 2011;185:60-6.

61 Heng DY, Wells JC, Rini BI, et al. Cytoreductive nephrectomy in patients with synchronous metastases from renal cell carcinoma: results from the International Metastatic Renal Cell Carcinoma Database Consortium. Eur Urol 2014;66:704-10.

62 Petrelli F, Coinu A, Vavassori I, et al. Cytoreductive nephrectomy in metastatic renal cell carcinoma treated with targeted therapies: a systematic review with a meta-analysis. Clin Genitourin Cancer 2016:14:465-72.

63 Heng DY, Xie W, Regan MM, et al. Prognostic factors for overall survival in patients with metastatic renal cell carcinoma treated with vascular endothelial growth factor-targeted agents: results from a large, multicenter study. J Clin Oncol 2009:27:5794-9.

64 Heng DY, Xie W, Regan MM, et al. External validation and comparison with other models of the International Metastatic Renal-Cell Carcinoma Database Consortium prognostic model: a population-based study. Lancet Oncol 2013;14:141-8. 
65 Alt AL, Boorjian SA, Lohse CM, et al. Survival after complete surgical resection of multiple metastases from renal cell carcinoma. Cancer 2011;117:2873-82.

66 Thomas AZ, Adibi M, Borregales LD, et al. Role of metastasectomy in metastatic renal cell carcinoma. Curr Opin Urol 2015;25:381-9.

67 Bianchi M, Sun M, Jeldres C, et al. Distribution of metastatic sites in renal cell carcinoma: a population-based analysis. Ann Oncol 2012;23:973-80.

68 Santini D, Procopio G, Porta C, et al. Natural history of malignant bone disease in renal cancer: final results of an Italian bone metastasis survey. PLOS One 2013;8:e83026.

69 Grünwald V, Eberhardt B, Bex A, et al. An interdisciplinary consensus on the management of bone metastases from renal cell carcinoma. Nat Rev Urol 2018;15:511-21.

70 NCCN Clinical Practice Guidelines in Oncology. Kidney Cancer. 2018.

71 Stenman M, Sinclair G, Paavola P, et al. Overall survival after stereotactic radiotherapy or surgical metastasectomy in oligometastatic renal cell carcinoma patients treated at two Swedish centres 2005-2014. Radiother Oncol 2018;127:501-6.

72 Meyer E, Pasquier D, Bernadou G, et al. Stereotactic radiation therapy in the strategy of treatment of metastatic renal cell carcinoma: A study of the Getug group. Eur J Cancer 2018;98:38-47.

73 Du Y, Pahernik S, Hadaschik B, et al. Impact of resection and systemic therapy on the survival of patients with brain metastasis of metastatic renal cell carcinoma. J Neurooncol 2016;130:221-8.

74 Maria B, Antonella V, Michela R, et al. Multimodality treatment of brain metastases from renal cell carcinoma in the era of targeted therapy. Ther $A d v$ Med Oncol 2016;8:450-9.

75 Johnson AG, Ruiz J, Hughes R, et al. Impact of systemic targeted agents on the clinical outcomes of patients with brain metastases. Oncotarget 2015;6:18945-55.

76 Chen L, Douglass J, Kleinberg L, et al. Concurrent immune checkpoint inhibitors and stereotactic radiosurgery for brain metastases in non-small cell lung cancer, melanoma, and renal cell carcinoma. Int J Radiat Oncol Biol Phys 2018; 100:916-25

77 Pike LRG, Bang A, Ott P, et al. Radiation and PD-1 inhibition: favorable outcomes after brain-directed radiation. Radiother Oncol 2017;124:98-103.

78 Minasian LM, Motzer RJ, Gluck L, et al. Interferon alfa-2a in advanced renal cell carcinoma: treatment results and survival in 159 patients with long-term follow-up. J Clin Oncol 1993;11:1368-75.

79 Quesada JR, Swanson DA, Gutterman JU. Phase II study of interferon alpha in metastatic renal-cell carcinoma: a progress report. J Clin Oncol 1985;3:1086-92.

80 Rosenberg SA, Lotze MT, Yang JC, et al. Prospective randomized trial of highdose interleukin-2 alone or in conjunction with lymphokine-activated killer cells for the treatment of patients with advanced cancer. J Nat/ Cancer Inst 1993;85:622-32.

81 Fyfe G, Fisher RI, Rosenberg SA, et al. Results of treatment of 255 patients with metastatic renal cell carcinoma who received high-dose recombinant interleukin-2 therapy. J Clin Oncol 1995;13:688-96.

82 Clark JI, Curti B, Davis E, et al. Long-term disease-free survival of patients with metastatic melanoma or renal cell cancer following high dose interleukin-2. Proc Soc Immunother Cancer 2017.

83 Dutcher JP, Wiernik PH. Interleukin-2 can cure kidney cancer, Letter to editor. The Oncologist 2018;23:e107.

84 McDermott DF, Cheng SC, Signoretti S, et al. The high-dose aldesleukin "select" trial: a trial to prospectively validate predictive models of response to treatment in patients with metastatic renal cell carcinoma. Clin Cancer Res 2015;21:561-8.

85 Payne $\mathrm{R}$, Glenn L, Hoen $\mathrm{H}$, et al. Durable responses and reversible toxicity of high-dose interleukin-2 treatment of melanoma and renal cancer in a Community Hospital Biotherapy Program. J Immunother Cancer 2014;2:13

86 Alva A, Daniels GA, Wong MK, et al. Contemporary experience with high-dose interleukin-2 therapy and impact on survival in patients with metastatic melanoma and metastatic renal cell carcinoma. Cancer Immunol Immunother 2016;65:1533-44

87 Fishman M, Clark Jl, Alva A, et al. Overall survival by clinical risk category for high dose Interleukin-2-treated metastatic renal cell cancer: Data from PROCLAIMTM. J Clin Oncol 2018;36(15S:260s.

88 Folkman J, Ingber D. Inhibition of angiogenesis. Semin Cancer Biol 1992;3:89-96.

89 Motzer RJ, Hutson TE, Tomczak P, et al. Sunitinib versus interferon alfa in metastatic renal-cell carcinoma. N Engl J Med 2007;356:115-24.

90 Escudier B, Eisen T, Stadler WM, et al. Sorafenib for treatment of renal cell carcinoma: Final efficacy and safety results of the phase III treatment approaches in renal cancer global evaluation trial. J Clin Oncol 2009;27:3312-8.
91 Hudes G, Carducci M, Tomczak P, et al. Temsirolimus, interferon alfa, or both for advanced renal-cell carcinoma. N Engl J Med 2007;356:2271-81.

92 Escudier B, Pluzanska A, Koralewski P, et al. AVOREN Trial investigators. Bevacizumab plus interferon alfa-2a for treatment of metastatic renal cell carcinoma. Lancet 2007;370:2103-11.

93 Sternberg CN, Davis ID, Mardiak J, et al. Pazopanib in locally advanced or metastatic renal cell carcinoma: results of a randomized phase III trial. J Clin Oncol 2010;28:1061-8.

94 Rini BI, Escudier B, Tomczak P, et al. Comparative effectiveness of axitinib versus sorafenib in advanced renal cell carcinoma (AXIS): a randomised phase 3 trial. Lancet 2011;378:1931-9.

95 Motzer RJ, Escudier B, Oudard S, et al. Phase 3 trial of everolimus for metastatic renal cell carcinoma : final results and analysis of prognostic factors. Cancer 2010;116:4256-65.

96 Choueiri TK, Escudier B, Powles T, et al. Cabozantinib versus everolimus in advanced renal cell carcinoma (METEOR): final results from a randomised, open-label, phase 3 trial. Lancet Oncol 2016;17:917-27.

97 Motzer RJ, Hutson TE, Glen H, et al. Lenvatinib, everolimus, and the combination in patients with metastatic renal cell carcinoma: a randomised, phase 2, open-label, multicentre trial. Lancet Oncol 2015;16:1473-82.

98 Khanna A, Crane A, Yerram N, et al. Contemporary management of advanced renal cell carcinoma. Clin Adv Hematol Oncol 2018;16:438-46.

99 Leach DR, Krummel MF, Allison JP. Enhancement of antitumor immunity by CTLA-4 blockade. Science 1996;271:1734-6.

100 Freeman GJ, Long AJ, Iwai Y, et al. Engagement of the PD-1 immunoinhibitory receptor by a novel $B 7$ family member leads to negative regulation of lymphocyte activation. J Exp Med 2000;192:1027-34.

101 Chen DS, Mellman I. Oncology meets immunology: the cancer-immunity cycle. Immunity 2013;39:1-10.

102 Pardoll DM. The blockade of immune checkpoints in cancer immunotherapy. Nat Rev Cancer 2012;12:252-64.

103 Yang JC, Hughes M, Kammula U, et al. Ipilimumab (anti-CTLA4 antibody) causes regression of metastatic renal cell cancer associated with enteritis and hypophysitis. J Immunother 2007;30:825-30.

104 Brahmer JR, Drake CG, Wollner I, et al. Phase I study of single-agent anti-programmed death-1 (MDX-1106) in refractory solid tumors: safety, clinical activity, pharmacodynamics, and immunologic correlates. J Clin Oncol 2010;28:3167-75.

105 McGregor BA, Flippot R, Choueiri T. Evolving role of TKI monotherapy in front line metastatic clear cell RCC. Kidney Cancer Journal 2018;16:83-7.

106 Gao X. Combination immunotherapy and targeted therapy: will new combinations raise the tail of the survival curve? Kidney Cancer Journal 2018;16:76-82.

107 Weinstock M, McDermott D. Targeting PD-1/PD-L1 in the treatment of metastatic renal cell carcinoma. Ther Adv Urol 2015;7:365-77.

108 Motzer RJ, Tannir NM, McDermott DF, et al. Nivolumab plus Ipilimumab versus Sunitinib in Advanced Renal-Cell Carcinoma. N Engl J Med 2018;378:1277-90.

109 Tannir N, Hammers H, Amin A. First-line vascular endothelial growth factor targeted therapy in renal cell carcinoma: priming the tumor microenvironment for immunotherapy. Curr Med Res Opin 2018;34:825-31.

110 Valenca LB, Hirsch MS, Choueiri TK, et al. Non-clear cell renal cell carcinoma, part 2: therapy. Clin Adv Hematol Oncol 2015;13:383-91.

111 Albiges L, Guegan J, Le Formal A, et al. MET is a potential target across all papillary renal cell carcinomas: result from a large molecular study of pRCC with CGH array and matching gene expression array. Clin Cancer Res 2014;20:3411-21.

112 Malouf GG, Joseph RW, Shah AY, et al. Non-clear cell renal cell carcinomas: biological insights and therapeutic challenges and opportunities. Clin Adv Hematol Oncol 2017:15:409-18.

113 Msaouel P, Hong AL, Mullen EA, et al. Updated Recommendations on the Diagnosis, Management, and Clinical Trial Eligibility Criteria for Patients With Renal Medullary Carcinoma. Clin Genitourin Cancer 201812.

114 Harrison MR. The landscape of adjuvant therapy: A controversy in search of a consensus. Kidney Cancer Journal 2018;16:88-92.

115 Haas NB, Manola J, Uzzo RG, et al. Adjuvant sunitinib or sorafenib for high-risk, non-metastatic renal-cell carcinoma (ECOG-ACRIN E2805) a double-blind, placebo-controlled, randomised, phase 3 trial. Lancet 2016;387:2008-16.

116 Motzer RJ, Haas NB, Donskov F, et al. Randomized phase III trial of adjuvant pazopanib versus placebo after nephrectomy in patients with localized or locally advanced renal cell carcinoma. J Clin Oncol 2017:35:3916-23.

117 pfizer. Recent pfizer press releases. 2018. https://www.pfizer.com/news/press release/presss-release detail/pfizer_provides_update_on_phase_3_trial_of 
axitinib_as_adjuvant_treatment_for_patients_at_high_risk_of_renal_cell_ carcinoma_recurrence_after_surgery

118 Ravaud A, Motzer RJ, Pandha HS, et al. Adjuvant sunitinib in high-risk renalcell carcinoma after nephrectomy. N Engl J Med 2016;375:2246-54.

119 Haas NB, Manola J, Dutcher JP, et al. Adjuvant treatment for high-risk clear cell renal cancer: updated results of a high-risk subset of the ASSURE Randomized Trial. JAMA Oncol 2017:3:1249-52.

120 Sternberg CN, Donskov F, Haas NB, et al. Pazopanib exposure relationship with clinical efficacy and safety in the adjuvant treatment of advanced renal cell carcinoma. Clin Cancer Res 2018;24:3005-13.

121 George DJ, Martini JF, Staehler M, et al. Immune biomarkers predictive for disease-free survival with adjuvant sunitinib in high-risk locoregional renal cell carcinoma: from randomized phase III S-TRAC Study. Clin Cancer Res 2018:24:1554-61.

122 Motzer RJ, Ravaud A, Patard JJ, et al. Adjuvant Sunitinib for high-risk renal cell carcinoma after nephrectomy: subgroup analyses and updated overall survival results. Eur Urol 2018;73:62-8.

123 Rini BI, Escudier B, Martini JF, et al. Validation of the 16-gene recurrence score in patients with locoregional, high-risk renal cell carcinoma from a phase iii trial of adjuvant sunitinib. Clin Cancer Res 2018;24:4407-15.
124 Priolo C, Khabibullin D, Reznik E, et al. Impairment of gamma-glutamyl transferase 1 activity in the metabolic pathogenesis of chromophobe renal cell carcinoma. Proc Natl Acad Sci U S A 2018;115:E6274-82.

125 Msaouel P, Tannir NM, Walker CL. A model linking sickle cell hemoglobinopathies and smarcb1 loss in renal medullary carcinoma. Clin Cancer Res 2018;24:2044-9.

126 Malouf GG, Compérat E, Yao H, et al. Unique transcriptomic profile of collecting duct carcinomas relative to upper tract urothelial carcinomas and other kidney carcinomas. Sci Rep 2016;6:30988.

127 Seo AN, Yoon G, Ro JY, Jy R. Clinicopathologic and Molecular Pathology of Collecting Duct Carcinoma and Related Renal Cell Carcinomas. Adv Anat Pathol 2017;24:65-77.

128 Lawrie CH, Armesto M, Fernandez-Mercado M, et al. Noncoding RNA expression and targeted next-generation sequencing distinguish tubulocystic renal cell carcinoma (tc-rcc) from other renal neoplasms. J Mol Diagn 2018;20:34-45.

129 Kondo T, Sasa N, Yamada H, et al. Acquired cystic disease-associated renal cell carcinoma is the most common subtype in long-term dialyzed patients: central pathology results according to the 2016 WHO classification in a multiinstitutional study. Pathol Int 2018;68:543-9. 